\title{
Kinetics of IFN- $\gamma$, TNF- $\alpha$, IL-10 and IL-4 production by mononuclear cells stimulated with gp43 peptides, in patients cured of paracoccidioidomycosis
}

\author{
Cinética da produção de IFN- $\gamma$, TNF- $\alpha$, IL-10 e IL-4 por células mononucleares, \\ de pacientes curados de paracoccidoidomicose, \\ estimuladas com peptídeos da gp43
}

\author{
Aya Sadahiro ${ }^{2}$, Constancia Lima Diogo ${ }^{1}$, Telma Miyuki Oshiro ${ }^{1}$ \\ and Maria Aparecida Shikanai-Yasuda ${ }^{1}$
}

\begin{abstract}
We analyzed the kinetics of cytokine production by mononuclear cells from 17 patients who had been treated for paracoccidioidomycosis, using the stimulus of gp43 peptide groups (43kDa glycoprotein of Paracoccidioides brasiliensis) at 0.1 and $1 \mu M$, gp43 (1 $\mathrm{g} / \mathrm{ml}$ ) and crude Paracoccidioides brasiliensis antigen (PbAg; $75 \mu \mathrm{g} / \mathrm{ml}$ ). IFN- $\gamma$ production was a maximum at 144 hours in relation to the G2 and G8 peptide groups at $1 \mu$ M and was greatest at 144 hours when stimulated by gp43 and by PbAg. The maximum TNF- $\alpha$ production was at 144 hours for the G2 group $(0.1 \mu M)$ and for gp43. IL-10 production was highest after 48 and 72 bours for $G 7$ and G6 at $1 \mu M$, respectively. We also suggest the best time for analysis of IL4 production. These results may contribute towards future studies with gp43 peptides and encourage further investigations with the aim of understanding the influence of these peptides on the production of inflammatory and regulatory cytokines.
\end{abstract}

Key-words: Paracoccidioidomycosis. Paracoccidioides brasiliensis. Gp43. Peptides. Cytokines.

\section{RESUMO}

Analisamos a cinética da produção de citocinas de células mononucleares de 17 pacientes com paracoccidioidomicose tratada, usando como

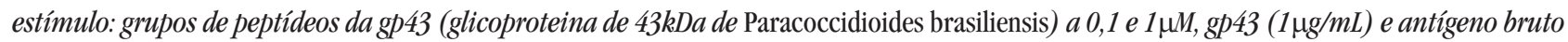
de Paracoccidioides brasiliensis - AgPb $(75 \mu \mathrm{g} / \mathrm{mL})$. A produção de IFN- $\gamma$ foi máxima em 144 horas frente aos grupos de peptídeos G2 e G8 a $1 \mu$ M e maior em 144 horas quando estimuladas por gp43 e por AgPb. A produção de TNF- $\alpha$ foi máxima em 144 horas para G2 $(0,1 \mu M)$ e para gp43. A produção de IL-10 foi maior após 48 e 72 horas para $G 7$ e $G 6$ a $1 \mu \mathrm{M}$, respectivamente. Sugerimos também o melhor período para a análise da produção de IL4. Tais resultados podem contribuir para estudos com peptídeos da gp43, estimulando investigações posteriores visando entender a influência de tais peptídeos na produção de citocinas inflamatórias e regulatórias.

Palavras-chaves: Paracoccidioidomicose. Paracoccidioides brasiliensis. Gp43. Peptídeos. Citocinas.

Paracoccidioidomycosis is a type of systemic mycosis caused by a dimorphic fungus, Paracoccidioides brasiliensis (P. brasiliensis). The host-fungus interaction without disease expression (i.e. in the absence of signs and symptoms) is known as paracoccidioidomycosis infection. Imbalance in this interaction leads to further fungal multiplication and lymphohematogenous dissemination and expression of the disease in children and young adults as the acute form of paracoccidioidomycosis. The chronic form reflects the reactivation of fungal lesions in the lungs or any other organ or tissue many years later in adult life ${ }^{22}$.

Evolution from infection to disease in its different clinical forms depends on many factors, such as environmental factors, host immune response and parasite virulence. As cell immunity plays an important role in resistance to this fungal infection, cytokine production has been widely investigated, and valuable

\footnotetext{
1. Laboratório de Imunologia, Departamento de Doenças Infecciosas e Parasitárias, Faculdade de Medicina, Universidade de São Paulo, São Paulo, SP. 2. Laboratório de Imunologia, Departamento de Parasitologia, Instituto de Ciências Biológicas, Universidade Federal do Amazonas, Manaus, AM.

This study received financial support from Fundação de Amparo à Pesquisa do Estado de São Paulo (FAPESP, Research Support Foundation for the State of São Paulo; grant no. 02/06481-6).

Address to: Dr. Maria Aparecida Shikanai-Yasuda. Rua Girassol 1211/64 Vila Madalena 05433-002 São Paulo, SP, Brazil.

Tel: 5511 3061-7048, Fax: 5511 3069-7507

e-mail: deptomi@usp.br,dmip.shikanai@hcnet.usp.br, lim48imuno@yahoo.com.br

Recebido para publicação em 22/8/2006
}

Aceito em 20/3/2007 
data to help understand the pathogenesis of the disease has become available 312141721 .

In experimental models, the presence of IFN- $\gamma$ and IL- 2 has been related to protection. Furthermore, preferential type 1 (Th1) response has been associated with a resistance phenotype. On the other hand, susceptibility is linked to a type 2 (Th2) response, with production of IL-4, IL-5, IL-10 and TGF- $\beta$ or production of the regulatory cytokines that are responsible for progressive paracoccidioidomycosis ${ }^{6}$.

Individuals with paracoccidioidomycosis infection without symptoms or signs of the disease present high levels of lymphocyte proliferation when stimulated by $P$. brasiliensis antigens, and also high levels of IFN- $\gamma$, but have low levels of IL-4, IL-5 and IL-10. Presence of the paracoccidioidomycosis infection is represented by the Th1 pole, and the acute form by the opposite pole, while patients with the chronic form have an intermediate immune response pattern between the Th2 and Th1 responses ${ }^{17}$.

Recently, the kinetics of cytokines were analyzed by mRNA expression in individuals with paracoccidioidomycosis infection and in patients with the chronic and acute forms of paracoccidioidomycosis. Early high expression of Th1 cytokines was observed in individuals with paracoccidioidomycosis infection, while in acute-form patients a predominance of Th2 cytokine mRNA was observed. In patients with the chronic form, a mixed pattern of Th1 and Th2 cytokine mRNA was detected. These findings suggest that the differential kinetic patterns and mRNA expression may significantly influence the outcome of paracoccidioidomycosis infection ${ }^{14}$.

The aim of this study was, for the first time, to evaluate the kinetics of cytokine production by mononuclear cells from patients who had been treated for paracoccidioidomycosis, using groups of peptides that constitute the gp 43 glycoprotein of $P$. brasiliensis as a stimulus.

\section{POPULATION AND METHODS}

Sample. Seventeen patients who had been successfully treated for paracoccidioidomycosis were selected at the Systemic Mycosis Outpatient Clinic of the Infectious and Parasitic Diseases Division, Hospital das Clínicas, University of São Paulo School of Medicine. Thirteen patients had chronic multifocal paracoccidioidomycosis, and four had the acute form of the disease.

At the time the patients were included in the study, they fulfilled the following criteria: a) they were clinically cured, with low levels or absence of antibodies, as shown by counterimmunoelectrophoresis (CIE); b) they had a positive paracoccidioidin test result or exhibited a lymphoproliferation response to gp 43 or crude $P$. brasiliensis antigen.

The clinical forms were defined according to the classification recommended in the International Colloquium on Paracoccidioidomycosis that was held in Medellín, Colombia, in $1986^{10}$

The Ethics Committee of Hospital das Clínicas approved the study design, and written informed consent was obtained from all patients. Brazilian Ministry of Health guidelines for human experimentation were followed strictly.

Gp43 peptides, gp43 and Paracoccidioides brasiliensis crude antigen. Forty-one gp 43 peptides obtained from P. brasiliensis isolate B339 ${ }^{16}$ (Genbank access number AY005437) were synthesized in the Biophysics Department Laboratory, Federal University of São Paulo (UNIFESP). Forty of them contained 15 amino acids, and one contained 16 (Table 1). These peptides were synthesized with a 10-amino acid overlap.

Table 1 - Gp43 peptide sequences.

\begin{tabular}{|c|c|c|}
\hline Peptide & Position & Amino Acid Sequence \\
\hline P1 & $(01-15)$ & MNFSSLNLALASCVL-NH $_{2}$ \\
\hline $\mathrm{P} 2$ & $(11-25)$ & ASCVLAWVCLASASS-NH ${ }_{2}$ \\
\hline $\mathrm{P} 3$ & $(21-35)$ & ASASSHVASHIVPRQ-NH $_{2}$ \\
\hline P4 & $(31-45)$ & IVPRQAGSAIYGVNI-NH \\
\hline P5 & $(41-55)$ & YGVNIGGWLLLEPWI-NH $_{2}$ \\
\hline $\mathrm{P} 6$ & $(51-65)$ & LEPWISPSVFEAGGS-NH \\
\hline P7 & $(61-75)$ & EAGGSSSVDEYTLSK-NH $_{2}$ \\
\hline P8 & $(71-85)$ & YTLSKNLGRDAKRHL-NH $_{2}$ \\
\hline P9 & $(81-95)$ & AKRHLSKHWDTFITE-NH ${ }_{2}$ \\
\hline P10 & $(91-105)$ & TFITEDDFKNIAAAG-NH ${ }_{2}$ \\
\hline P11 & $(101-115)$ & IAAAGLNHVRIPIGY-NH $_{2}$ \\
\hline P12 & $(111-125)$ & IPIGYWAVNPIEGEP-NH $_{2}$ \\
\hline P13 & $(121-135)$ & IEGEPYVQGQLDYLD-NH ${ }_{2}$ \\
\hline P14 & $(131-145)$ & LDYLDKALVWAKNSN-NH $_{2}$ \\
\hline P15 & $(141-155)$ & AKNSNLRVVIDLHGV-NH ${ }_{2}$ \\
\hline P16 & $(151-165)$ & DLHGVPGSQNGFDNS-NH ${ }_{2}$ \\
\hline P17 & $(161-175)$ & GFDNSGHRGAINWQK-NH $_{2}$ \\
\hline P18 & $(171-185)$ & INWQKGDTIKQTLIA-NH \\
\hline P19 & $(181-195)$ & QTLIAIHTLAIRYAN-NH ${ }_{2}$ \\
\hline P20 & $(191-205)$ & IRYANRTDVVDSIEL-NH $_{2}$ \\
\hline P21 & $(201-215)$ & DSIELVNKPSIPGGV-NH $_{2}$ \\
\hline P22 & $(211-225)$ & IPGGVQVSLLKEYYE-NH $_{2}$ \\
\hline P23 & $(221-235)$ & KEYYEDGYHIVRDID-NH ${ }_{2}$ \\
\hline P24 & $(231-245)$ & VRDIDSTVGVAISDA-NH ${ }_{2}$ \\
\hline P25 & $(241-255)$ & AISDASLPPRTWNGF-NH $_{2}$ \\
\hline P26 & $(251-265)$ & TWNGFLAPKTYKNVY-NH ${ }_{2}$ \\
\hline P27 & $(261-275)$ & YKNVYLDTYHNQVFD-NH $_{2}$ \\
\hline P28 & $(271-285)$ & NQVFDDIFRTFTIDQ-NH \\
\hline P29 & $(281-295)$ & FTIDQHVKLACSLPH-NH \\
\hline P30 & $(291-305)$ & CSLPHDRLRGADKPL-NH $_{2}$ \\
\hline $\mathrm{P} 31$ & $(301-315)$ & ADKPLIVKEWSGAMT-NH ${ }_{2}$ \\
\hline $\mathrm{P} 32$ & $(311-325)$ & SGAMTDCAMYLNGRG-NH $_{2}$ \\
\hline P33 & $(321-335)$ & LNGRGIGSRFDGSFP-NH ${ }_{2}$ \\
\hline P34 & $(331-345)$ & DGSFPSGKPSGACGA-NH $_{2}$ \\
\hline P35 & $(341-355)$ & GACGARSKGSSSELS-NH $_{2}$ \\
\hline P36 & $(351-365)$ & SSELSAQQKKDTLRY-NH $_{2}$ \\
\hline P37 & $(361-375)$ & DTLRYIEAQLDAFEV-NH $_{2}$ \\
\hline P38 & $(371-385)$ & DAFEVAAGWYFWTWK-NH ${ }_{2}$ \\
\hline P39 & $(381-395)$ & FWTWKTEGAPGWDMQ-NH \\
\hline P40 & $(391-405)$ & GWDMQDLLNQKLFPQ- $\mathrm{NH}_{2}$ \\
\hline P41 & $(401-416)$ & KLLPQPIWARKYGGCR-NH $_{2}$ \\
\hline
\end{tabular}


Gp43 was kindly provided by Professor Luiz R. Travassos of UNIFESP and was produced in accordance with Puccia et $\mathrm{al}^{20}$. P. brasiliensis crude antigen ( $\mathrm{PbAg}$ ) was provided by Professor Gil Benard of the University of São Paulo (USP) and was prepared in accordance with Benard et $\mathrm{al}^{1}$.

Measurement of cytokines from cell-culture supernatants. Peripheral blood mononuclear cells (PBMC) were isolated by density-gradient centrifugation $(\delta=1,077)$. Cells were cultivated in RPMI 1640 medium supplemented with $10 \%$ Fetal Bovine Serum and $5 \mathrm{mML}$-glutamine, in triplicate 96 -well flat-bottom culture plates $\left(2.5 \times 10^{5}\right.$ cells/well, final volume $\left.0.2 \mathrm{ml}\right)$ at $37^{\circ} \mathrm{C}$ and $5 \% \mathrm{CO}_{2}$ for 48,72 and 144 hours. The cells were stimulated with 41 gp 43 peptides distributed into seven groups containing five peptides each and one group containing six peptides: G1 (P1, P2, P3, P4 and P5); G2 (P6, P7, P8, P9 and P10); G3 (P11, P12, P13, $\mathrm{P} 14$ and P15); G4 (P16, P17, P18, P19 and P20); G5 (P21, P22, P23, P24 and P25); G6 (P26, P27, P28, P29 and P30); G7 (P31, P32, P33, P34 and P35) and $\mathbf{G 8}$ (P36, P37, P38, P39, P40 and $\mathrm{P} 41)$. The peptides were tested at concentrations of 0.1 and $1 \mu \mathrm{M}$. P. brasiliensis crude antigen ( $\mathrm{PbAg})(75 \mu \mathrm{g} / \mathrm{ml})$ and purified gp 43 $(1 \mu \mathrm{g} / \mathrm{ml})$ were also used for stimulating cytokine production.

Culture supernatants were harvested after 48, 72 and 144 hours and stored at $-80^{\circ} \mathrm{C}$ before the assay. The cytokine levels were measured by ELISA. The assay was performed in 96-well plates (Nunc) coated with mice anti-human IFN- $\gamma$, TNF- $\alpha$, IL-10 or IL-4 antibodies (R\&D) and blocked with bovine serum albumin (BSA) fraction V (Sigma) in PBS buffer or reagent diluent at $\mathrm{pH}$ 7.2. Biotinylated anti-human IFN- $\gamma$, TNF- $\alpha$, IL-10 or IL-4 antibodies were used. The ELISA procedure was performed according to the manufacturer's protocol. The lowest detection limits for IFN- $\gamma$, TNF- $\alpha$, IL-10 and IL-4 were $15,625 \mathrm{pg} / \mathrm{ml}, 7,813 \mathrm{pg} / \mathrm{ml}$, $62,500 \mathrm{pg} / \mathrm{ml}$ and $15,625 \mathrm{pg} / \mathrm{ml}$, respectively.

Statistical analysis. Analysis of cytokine secretion after different stimulus durations was performed by analysis of variance for non-parametric data with repeated measurements (Friedman's test) and multiple comparisons with Dunn's test ${ }^{7} . P$ values under 0.05 were considered significant.

\section{RESULTS}

Determination of IFN- $\gamma$ levels. The production of IFN- $\gamma$ from the 17 paracoccidioidomycosis patients was higher at 144 hours than at 48 hours for the $\mathrm{G} 2(p=0,0213)$ and $\mathrm{G} 8(p=0,0033)$ gp 43 -peptide groups at $1 \mu \mathrm{M}$ concentration. Figures $1 \mathrm{~A}$ and $1 \mathrm{~B}$ show the IFN- $\gamma$ levels in the supernatants from the patients' cell cultures stimulated by G2 and G8 peptides, respectively. The G4 group of peptides induced IFN- $\gamma$ production in four patients, with the concentration of some supernatants exceeding 300pg/ml when stimulated for 144 hours, although there were no statistically significant differences in IFN- $\gamma$ production for any of these peptides (data not shown).

For gp 43 and $P$. brasiliensis crude antigen $(\mathrm{PbAg})$, statistically significant differences were found between IFN- $\gamma$ levels at 144 hours and those at 48 and 72 hours ( $p=0,0001$ for both antigens). Figures 1C and 1D show high levels of IFN- $\gamma$ secretion after stimulation by both gp 43 and PbAg. In some patients with the acute

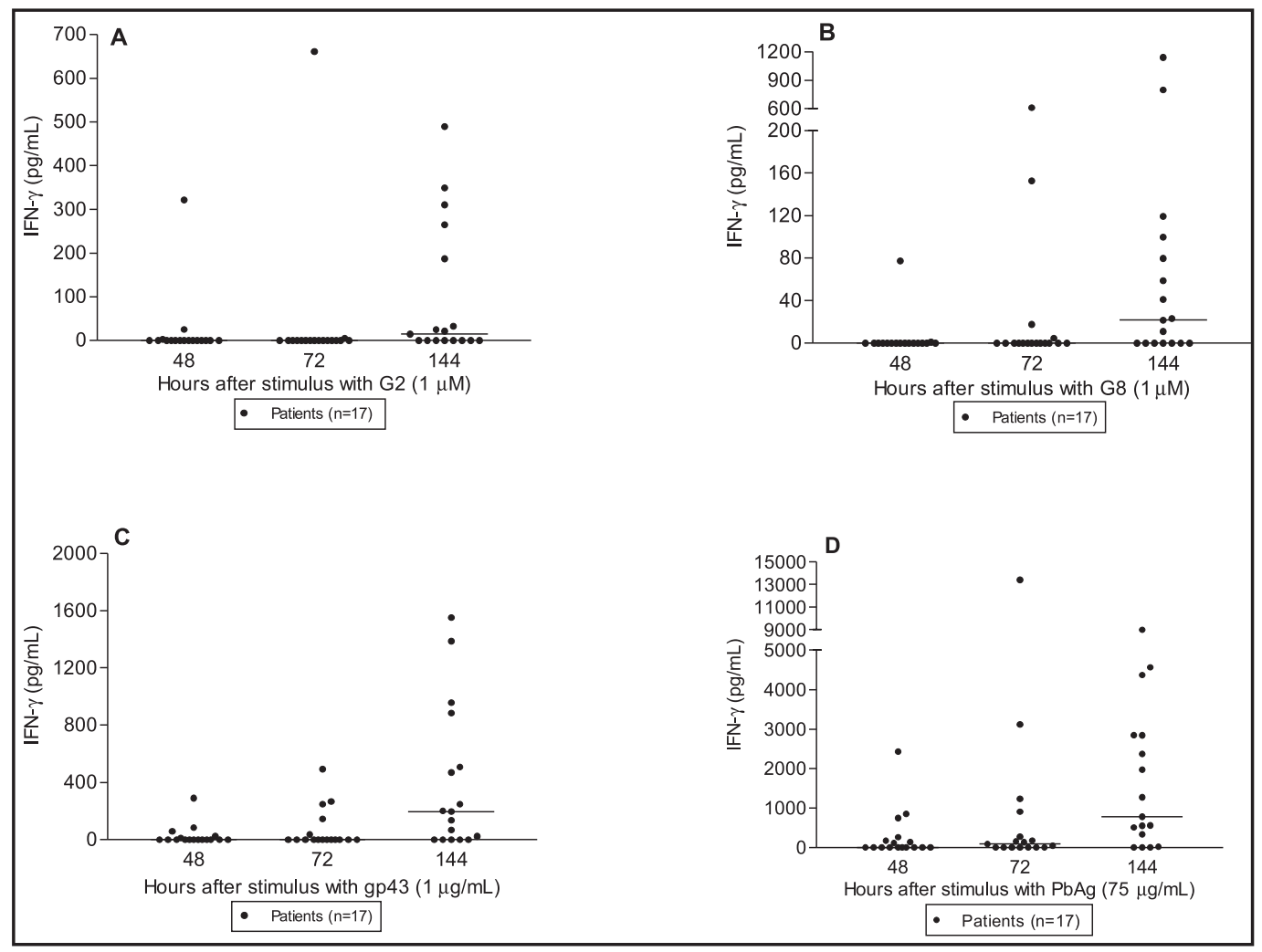

Figure 1 - IFN- $\gamma$ levels in supernatants from mononuclearcell cultures from cured paracoccidioidomycosis patients, with stimulation using G2 peptides (A) (48h vs. 144h, p=0,0213) and G8 peptides (B) (48h vs. 144h, p=0,0033), gp43 (C) (48 and $72 \mathrm{~h}$ vs. $144 \mathrm{~h}$, $p=0,0001$ ) and PbAg (D) (48 and $72 \mathrm{~b}$ vs. 144h, $p=0,0001$ ) for 48, 72 and 144 bours. The horizontal bars represent medians. 
form of paracoccidioidomycosis, cells that were reactive to gp 43 produced high levels of IFN- $\gamma$ (data not shown).

Determination of TNF- $\alpha$ levels. The levels of TNF- $\alpha$ production in the 17 patients treated for paracoccidioidomycosis were higher at 144 hours than at 48 hours in mononuclear cells stimulated with $\mathrm{G} 2$ peptides $(p=0,0020)$ at $0.1 \mu \mathrm{M}$ and gp43 $(p=0,0008)$. Figures $2 \mathrm{~A}$ and $2 \mathrm{~B}$ show the TNF- $\alpha$ levels in supernatants from the patients' cell cultures stimulated by G2 and gp43, respectively. Four patients with the acute form of paracoccidioidomycosis produced TNF- $\alpha$ after stimulus with gp 43. Of these, two had TNF- $\alpha$ levels greater than $1,000 \mathrm{pg} / \mathrm{ml}$ (Figure 2B). Other peptides induced TNF- $\alpha$ production in the majority of patients, but no significant differences were observed between the durations of stimulation (Figures $3 \mathrm{~A}$ and $3 \mathrm{~B}$ ).

Determination of IL-10 levels. IL-10 levels were higher in supernatants from 17 patient mononuclear-cell cultures stimulated with the $\mathrm{G} 7$ group of peptides at $1 \mu \mathrm{M}(p=0,0438)$ after 48 hours than after 144 hours. Figure 4A shows IL-10 levels in supernatants of patients cell cultures stimulated by G7. However, when the cells were stimulated with the $\mathrm{G} 6$ group of peptides at $1 \mu \mathrm{M}$ $(p=0,0260)$, IL-10 levels were higher at 72 hours than at 144 hours (data not shown).

G3 group of peptides at $0.1 \mu \mathrm{M}$ induced IL-10 production in patients cured of the chronic multifocal form of the disease although no statistically significant differences were found between the different periods (Figure 4B).

Determination of IL-4 levels. IL-4 was detected at low levels in most of the cell-culture supernatants. However, this cytokine level tended to be higher at 72 hours when stimulated by $\mathrm{G} 2$ peptides at $0.1 \mu \mathrm{M}(p=0,0595)$ and at 48 hours when stimulated by $\mathrm{G} 6$ peptides at $1 \mu \mathrm{M}(p=0,0581)$. However, the results were not statistically significant for the time periods studied (data not shown).

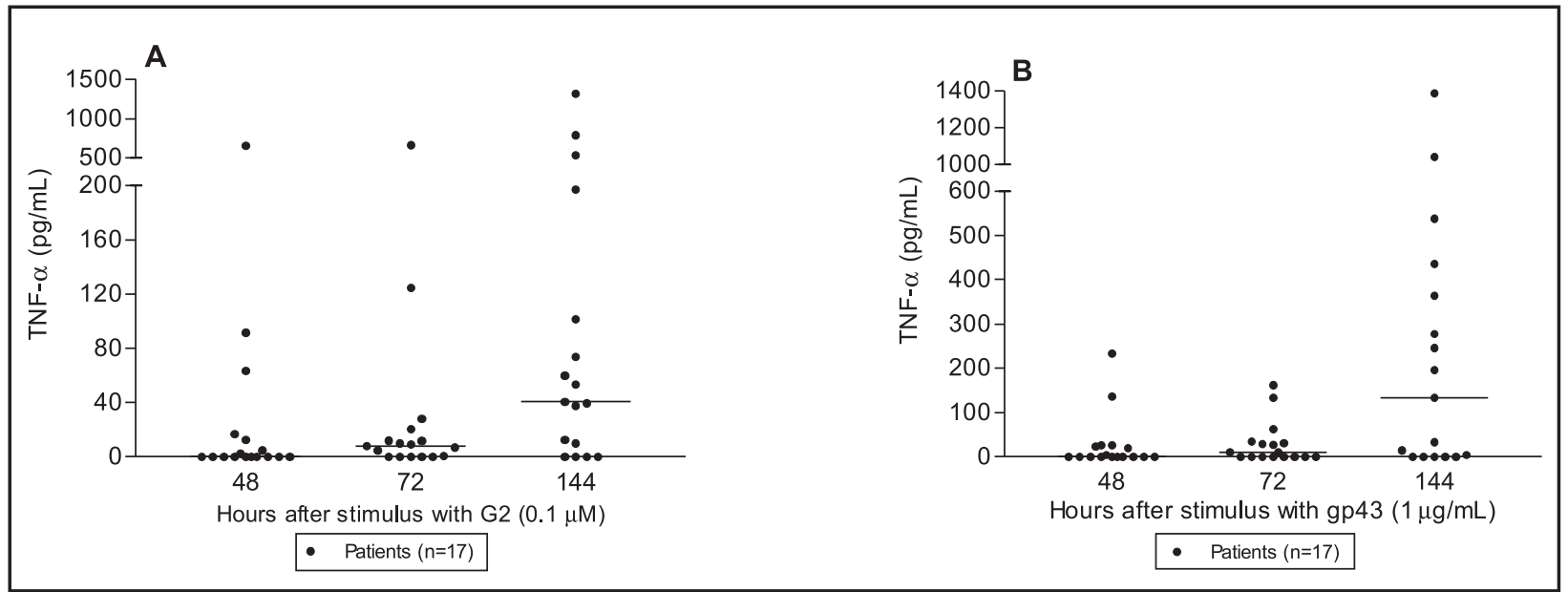

Figure 2 - TNF- $\alpha$ levels in supernatants from mononuclear cell cultures from cured paracoccidioidomycosis patients, with stimulation using G2-group peptides (A) (48h vs. 144h, p=0,0020) and gp43 (B) (48 and $72 \mathrm{~b}$ vs. 144h, $p=0,0008)$ for 48,72 and 144 hours. The horizontal bars represent medians.

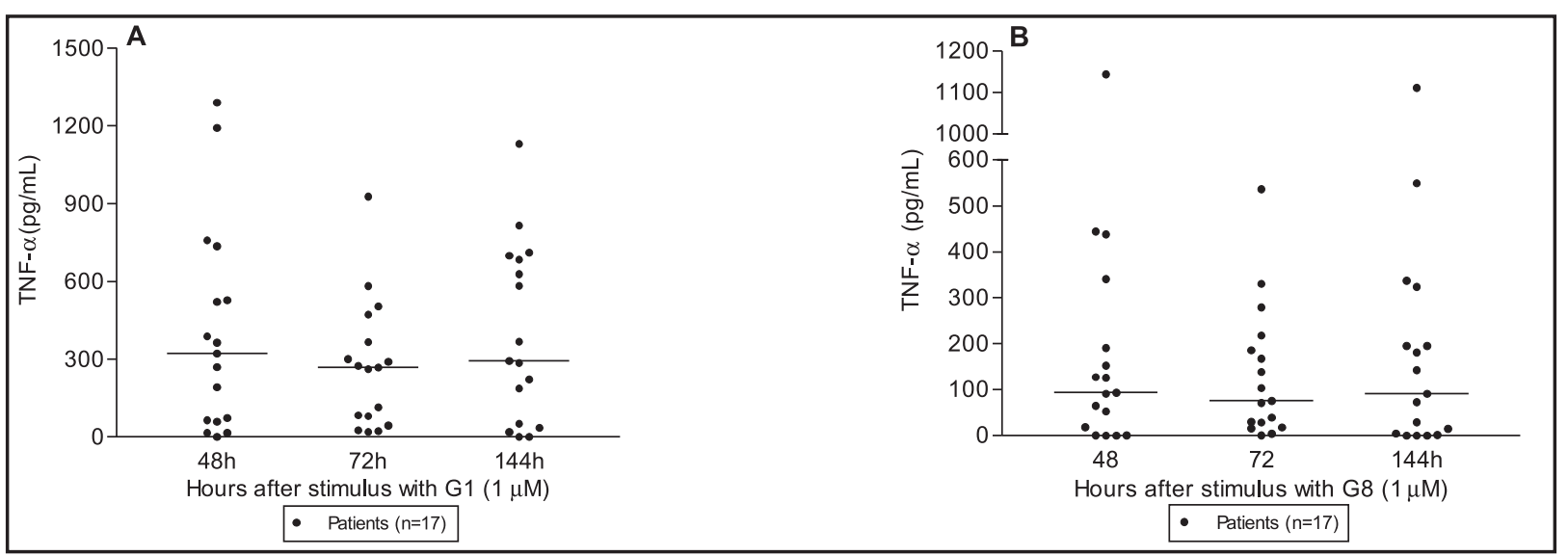

Figure 3 - TNF- $\alpha$ levels in supernatants from mononuclear cell cultures from cured paracoccidioidomycosis patients, with stimulation using $G 1$ (A) and G8 (B), for 48, 72 and 144 hours. The horizontal bars represent medians. 


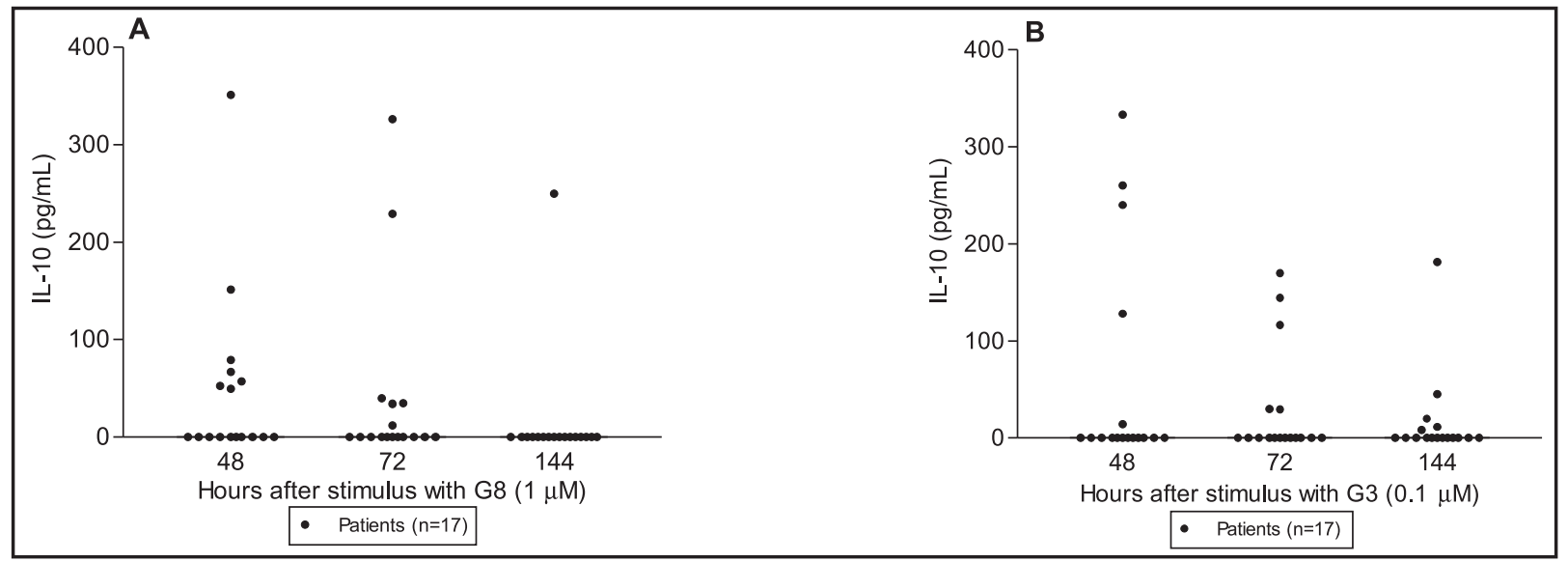

Figure 4 - IL-10 levels in supernatants from mononuclear cell cultures from cured paracoccidioidomycosis patients, with stimulation using G7-group peptides (A), G3-group peptides (B), for 48, 72 and 144 bours.

\section{DISCUSSION}

The present study was performed using cells from clinically cured patients, because patients with active paracoccidioidomycosis present transitory cell immunosuppression to antigens from P. brasiliensis, whereas this response is restored following clinical cure $^{2}$. The best stimulus duration observed for IFN- $\gamma$ production in mononuclear cell cultures from treated paracoccidioidomycosis patients was 144 hours for two groups of gp 43 peptides (G2 and G8), for P. brasiliensis crude antigen (PbAg) and for P. brasiliensis gp 43 glycoprotein.

A number of authors who studied cytokines in human paracoccidioidomycosis, using similar lymphoproliferation assays with mononuclear cells, used stimulus periods of 48 to 96 hours for IFN- $\gamma$ analyses ${ }^{312}{ }^{17}$. The differences between the stimulus duration for IFN- $\gamma$ production in those studies and the stimulus duration in our study may be due to the different techniques used for obtaining and purifying $P$. brasiliensis antigens. In experimental work with BALB/c mice using the gp 43 and P10 (gp43[181-195]) peptides, the best length of time found for IFN- $\gamma$ detection was the same as in the present study, namely 144 hours ${ }^{24}$, which confirms this result.

Analysis of IFN- $\gamma$ mRNA expression stimulated with PHA suggests that low levels of IFN- $\gamma$ in the acute form indicate that the initial phase of host interaction with $P$. brasiliensis is followed by the Th2 cytokine pattern and increased levels of non-protective fungal antibodies ${ }^{14}$. Only after specific therapy and control of fungus multiplication was recovery of cellular response and a drop in antibody levels observed.

It is important to note that several studies have shown that IFN- $\gamma$ plays an essential role in resistance to paracoccidioidomycosis and that it is associated with cell-mediated immunity, which is critical for host defense against $P$. brasiliensi ${ }^{13}{ }^{17}$. Furthermore, studies in animal models have been described in which IFN- $\gamma$-activated macrophages represent one of the most important mechanisms against this pathogen and induce a fungicidal effect ${ }^{48}$. This process is nitric-oxide dependent ${ }^{11}$.
For TNF- $\alpha$, the peak production with $\mathrm{G} 2$ peptides $(0.1 \mu \mathrm{M})$ and gp 43 was found to be at 144 hours (Figures $2 \mathrm{~A}$ and 2B). This result was interesting because most other studies analyzed the production or expression of these cytokines between six and 72 hours after stimulus with different types of antigens ${ }^{9} 121819$. TNF- $\alpha$ mRNA expression in cells from individuals with paracoccidioidomycosis infection peaked three hours after stimulus with $\mathrm{PHA}^{14}$. In our study, this cytokine was detected in the majority of the peptide groups tested for almost all the durations of stimulation (Figures $3 \mathrm{~A}$ and 3B) although TNF- $\alpha$ production was higher after 144 hours for $\mathrm{G} 2$ peptides and $P$. brasiliensis gp 43 glycoprotein (Figures 2A and 2B).

The high levels of IFN- $\gamma$ and TNF- $\alpha$ production found in cell cultures from the cured patients in our study after 144 hours of stimulation with gp43 suggest that in some cases the antigen-specific immunosuppression was transitory and immune reactivity to gp 43 was recovered after the treatment, as reported by Benard et $\mathrm{al}^{2}$. Moreover, the present finding of reactivity to gp43 peptides, in particular to the $\mathrm{G} 2$ and $\mathrm{G} 8$ peptides, is helpful in understanding the immunopathogenesis of the disease and has possible applications in immunotherapy and immunoprophylaxis. As reported in the literature, P10 peptide stimulated IFN- $\gamma$ production in a murine model and provided protection against virulent $P$. brasiliensi ${ }^{2324}$, thus corroborating the findings of our study in human paracoccidioidomycosis cells stimulated by the G4 peptide group, which contains the same peptide (P19 in our study) as the one involved in the protection of mice against P. brasiliensis (P10).

In the present study, IL-10 was detected for two groups of peptides - $\mathrm{G} 7(1 \mu \mathrm{M})$ and $\mathrm{G} 6(1 \mu \mathrm{M})$ - and the best stimulus durations observed were 48 and 72 hours, respectively. Studies carried out with $P$. brasiliensis antigens have described detection of IL-10 after stimulation of between 18 and 72 hours $^{35151718}$. In human paracoccidioidomycosis, IL-10 appears to perform a regulatory function in the apoptosis process, thereby avoiding the loss of reactive cells during infection by $P$. brasiliensi ${ }^{5}$. However, so far, only gp 43 has been tested, and none of its epitopes are known to stimulate the production of this regulatory cytokine. High 
levels of this cytokine observed in supernatants of cell cultures from patients with active disease ${ }^{317}$ may be important in limiting the loss of reactive cells. IL-10 was also detected at high levels in treated paracoccidioidomycosis patients when the cells were stimulated in vitro with PHA and $P$. brasiliensis antigens ${ }^{3}{ }^{12}$. In our study, the presence of IL-10 in the supernatants of the patients' cell cultures suggests that this regulatory response persists, even if treatment had been interrupted many months or years before.

The levels at which the IL- 4 cytokine was detected in cultured supernatants were low in most of the samples analyzed, and no statistically significant difference was observed between the results from the different durations of stimulation. However, IL-4 was detected at 48 and 72 hours when stimulated with $\mathrm{G} 6(1 \mu \mathrm{M})$ and $\mathrm{G} 2(0.1 \mu \mathrm{M})$ respectively. These low levels of detection may be explained because these patients had already been cured. IL- 4 was detected in cell culture supernatants from patients with active paracoccidioidomycosis, following stimulation with $P$. brasiliensis antigen, and was strongly detected in patients with the acute form of the disease ${ }^{17}$. Furthermore, high levels of IL-4 mRNA expression were observed in patients with the acute and chronic forms up to 24 hours after stimulus with PHA $^{14}$, thus suggesting that IL- 4 has a role in the Th2 response at this phase of the disease. Low levels of IL-4 or failure to detect this cytokine in cell-culture supernatants from treated patients could be related to the absence or low levels of antibodies, since the presence of this cytokine has been associated with the presence of IgG4 antibodies in the active phase of the illness. The presence of this cytokine in the supernatants of some cured patients' cells (data not shown) suggests that, even after a long period of treatment, the immune response is not restored in some patients.

Our results indicate the best time for detection of IFN- $\gamma$, TNF- $\alpha$ and IL-10 in supernatants from cultures stimulated by gp 43, crude P. brasiliensis antigens and groups of gp 43 peptides and also suggest the best time for detection of IL-4. These data may contribute towards future studies on the role of gp 43 peptides and gp 43 in the host immune response relating to paracoccidioidomycosis. In addition, increased levels of IFN- $\gamma$ and TNF- $\alpha$ were observed in cells from paracoccidioidomycosis patients in response to stimulation by gp 43 and gp 43 peptides, thus encouraging further research towards understanding the influence of gp 43 peptides on the production of inflammatory and regulatory cytokines.

\section{ACKNOWLEDGMENTS}

We wish to thank Rosana Prisco from the Institute of Biomedical Sciences, University of São Paulo, for the statistical analysis.

\section{REFERENCES}

1. Benard G, Durandy A, Assis CM, Hong MA, Orii M, Sato MN, Mendes-Gianini MJ, Lacaz CS, Duarte AJS. Responses of T and B lymphocytes to a Paracoccidioides brasiliensis cell wall extract in healthy sensitized and nonsensitized subjects responses. The American Journal of Tropical Medicine and Hygiene 53:189-194, 1995.

2. Benard G, Hong MA, Del Negro GMB, Batista L, Shikanai-Yasuda MA, Duarte AJS. Antigen-specific immunosuppression in paracoccidioidomycosis. The American Journal of Tropical Medicine and Hygiene 54:7-12, 1996.
3. Benard G, Romano CC, Cacere CR, Juvenale M, Mendes-Giannini MJS, Duarte AJS. Imbalance of IL-2, IFN- $\gamma$ and IL-10 secretion in the immunosuppression associated with human paracoccidioidomycosis. Cytokine 13:248-252, 2001.

4. Brummer E, Hanson LH, Restrepo A, Stevens DA. In vivo and in vitro activation of pulmonary macrophages by IFN-gama for enhanced killing of Paracoccidioides brasiliensis or Blastomyces dermatitidis. Journal of Immunology 140:27862789, 1988.

5. Cacere CR, Romano CC, Mendes Giannini MJ, Duarte AJ, Benard G. The role of apoptosis in the antigen-specific $\mathrm{T}$ cell hyporesponsiveness of paracoccidioidomycosis patients. Clinical Immunology 105:215-222, 2002.

6. Calich VLG, Kashino SS. Cytokines produced by susceptible and resistant mice in the course of Paracoccidioides brasiliensis infection. Brazilian Journal of Medical and Biological Research 31:615-623, 1998.

7. Callegari-Jacques SM. Bioestatística: princípios e aplicações. Artmed, Porto Alegre, 2003.

8. Cano LE, Kashino SS, Arruda C, André D, Xidieh CF, Singer-Vermes LM, Vaz CAC, Burger E, Calich VLG. Protective role of gamma interferon in experimental pulmonary paracoccidioidomycosis. Infection and Immunity 66:800-806, 1998.

9. Diniz SN, Cisalpino PS, Freire AT, Silva-Teixeira DN, Contigli C, Rodrigues Junior $\mathrm{V}$, Goes AM. In vitro granuloma formation, NO production and cytokines profile from human mononuclear cells induced by fractionated antigens of Paracoccidioides brasiliensis. Human Immunology 62:799-808, 2001.

10. Franco M, Montenegro MR, Mendes RP, Marques SA, Dillon NL, Mota NG. Paracoccidiodomycosis: a recently proposed classification of its clinical forms. Revista da Sociedade Brasileira de Medicina Tropical 20:129-132, 1987.

11. Gonzalez A, Gregori W, Velez D, Restrepo A, Cano LE. Nitric oxide participation in the fungicidal mechanism of gamma interferon-activated macrophages against Paracoccidioides brasiliensis conidia. Infection and Immunity 68:2546-2552, 2000.

12. Karhawi AS, Colombo AL, Salomão R. Production of IFN- $\gamma$ is impaired in patients with paracoccidioidomycosis during active disease and is restored after clinical remission. Medical Mycology 38:225-229, 2000.

13. Kashino SS, Fazioli RA, Cafalli-Favati C, Meloni-Bruneri LH, Vaz CA, Burger E, Singer LM, Calich VL. Resistance to Paracoccidioides brasiliensis infection is linked to a preferential Th1 immune response, whereas susceptibility is associated with absence of IFN-gamma production. Journal of Interferon \& Cytokine Research 20:89-97, 2000.

14. Mamoni RL, Blotta MH. Kinetics of cytokines and chemokines gene expression distinguishes Paracoccidioides brasiliensis infection from disease. Cytokine 32:20-29, 2005.

15. Mello LM, Silva-Vergara ML, Rodrigues Jr V. Patients with active infection with Paracoccidioides brasiliensis present a Th2 immune response characterized by high Interleukin-4 and Interleukin-5 production. Human Immunology 63:149154,2002

16. Morais FV, Barros TF, Fukada MK, Cisalpino PS, Puccia R. Polymorphism in the gene coding for the immunodominant antigen gp 43 from the pathogenic fungus Paracoccidioides brasiliensis. Journal of Clinical Microbiology 38:3960-3966, 2000.

17. Oliveira SJ, Mamoni RL, Musatti CC, Papaiordanou PM, Blotta MH. Cytokines and lymphocyte proliferation in juvenile and adult forms of paracoccidioidomycosis: comparison with infected and non-infected controls. Microbes and Infection 4:139-144, 2002.

18. Peraçoli MT, Kurokawa CS, Calvi SA, Mendes RP, Pereira PC, Marques SA, Soares AM. Production of pro- and anti-inflammatory cytokines by monocytes from patients with paracoccidioidomycosis. Microbes and Infection 5:413-418, 2003.

19. Pereira CB, Palaci M, Leite OH, Duarte AJ, Benard G. Monocyte cytokine secretion in patients with pulmonary tuberculosis differs from that of healthy infected subjects and correlates with clinical manifestations. Microbes and Infection 6:25-33, 2004.

20. Puccia R, Schenkeman S, Gorin PA, Travassos LR. Exocellular components of Paracoccidioides brasiliensis. Identification of a specific antigen. Infection and Immunity 53:199-206, 1986.

21. Romano CC, Mendes-Giannini MJ, Duarte AJ, Benard G. IL-12 and neutralization of endogenous IL-10 revert the in vitro antigen-specific cellular immunosuppression of paracoccidioidomycosis patients. Cytokine 18:149-157, 2002. 
22. Shikanai-Yasuda MA. Pharmacological management of paracoccidioidomycosis. Expert Opinion on Pharmacotherapy 6:385-397, 2005.

23. Taborda CP, Juliano MA, Puccia R, Franco M, Travassos LR. Mapping of the T-cell epitope in the major 43-Kilodalton glycoprotein of Paracoccidioides brasiliensis which induces a Th1 response protective against fungal infection in Balb/c mice. Infection and Immunity 66:786-793, 1998.
24. Taborda CP, Nakaie CR, Cilli EM, Rodrigues EG, Silva LS, Franco MF, Travassos LR. Synthesis and immunological activity of a branched peptide carrying the T-cell epitope of gp43, the major exocellular antigen of Paracoccidioides brasiliensis. Scandinavian Journal of Immunology 59:58-65, 2004 